\title{
KARAKTERISTIK AGRONOMI KACANG TANAH (Arachis hypogaea L.) PADA PEMBERIAN MIKROORGANISME LOKAL (MOL) REBUNG DI LAHAN MASAM
}

\author{
Ego Saputra $^{1)}$, Setiono $^{2)}$ dan Effi Yudiawati ${ }^{3)}$ \\ 1,2,3 Program Studi Agroteknologi Fakultas Pertanian \\ Universitas Muara Bungo \\ Email : tiosetiono18@ gmail.com
}

Naskah diterima November 2018, disetujui Maret 2019

\begin{abstract}
ABSTRAK
Penelitian ini dilaksanakan di kebun percobaan Fakultas Pertanian Universitas Muara Bungo Sungai Binjai KM 6 Kabupaten Bungo, dengan ketinggian $\pm 101 \mathrm{~m}$ dpl, dengan curah hujan 248,75 mm/bulan. Penelitian dilakukan pada bulan Juni hingga September 2018. Penelitian ini bertujuan untuk mengetahui karakteristik agronomi kacang tanah (Arachis hypogaea L.) di lahan masam pada pemberian mikroorganisme lokal (MOL) rebung bambu dan mendapatkan kosentrasi MOL yang terbaik terhadap karakteristik agronomi kacang tanah (Arachis hypogaea L.) di lahan masam Kabupaten Bungo.

Penelitian ini menggunakan Rancangan Acak Kelompok (RAK) dengan 5 perlakuan dan 4 kelompok yaitu : M0 (0 ml/liter air), M (10 ml/liter air), M2 (20 ml/liter air), M3 (30 $\mathrm{ml} /$ liter air) dan M4 (40 ml/liter air). Adapun parameter yang diamati adalah tinggi tanaman $(\mathrm{cm})$, jumlah tangkai daun (batang), (cm), jumlah polong pertanaman (buah), berat polong kering pertanaman (g) dan hasil polong kering per hektar (ton). Hasil pengamatan dianalisis secara statistik dengan analisis ragam dan apabila terdapat pengaruh nyata maka dilanjutkan dengan uji duncan's multiple range test (DNMRT) taraf 5\%.

Hasil penelitian menunjukan bahwa karakteristik agronomi tinggi tanaman, jumlah tangkai daun dan jumlah polong pertanaman, kacang tanah tidak ditentukan oleh pemberian MOL rebung bambu karena tidak berpengaruh nyata sedangkan berat polong kering pertanaman dan hasil polong kering perhektar kacang tanah di lahan masam dalam penelitian ini ditentukan oleh pemberian MOL rebung bambu karena berpengaruh nyata. Perlakuan MOL rebung bambu perlakuan M2 (20 ml/liter air) merupakan konsentrasi yang terbaik meningkatkan karakteristik agronomi kacang tanah di lahan masam
\end{abstract}

Kata Kunci : MOL rebung, kacang tanah, lahan masam

\section{PENDAHULUAN}

Salah satu jenis kacangan yang telah dibudidayakan secara luas di Indonesia adalah kacang tanah (Arachis hypogaea L.). Kacang tanah merupakan salah satu komoditi tanaman pangan bernilai ekonomis dan strategis dalam upaya meningkatkan pendapatan dan perbaikan gizi masyarakat. Beberapa hal menjadi peluang bagi pengembangan produksi kacang tanah adalah : permintaan yang cenderung terus meningkat untuk konsumsi dan industri olahan (dibuat menjadi tahu, minyak, pasta, cookis rendah lemak, susu dan kosmetik), 
memiliki keunggulan produk bagi pangan pokok dan pangan sehat, memiliki alternatif produk turunan (pangan, pakan), kesenjangan produktivitas di lapangan dan potensi hasil, dan tersedianya paket teknologi baru dan sumberdaya manusia yang cukup terampil dalam usaha kacang tanah. Sebagai bahan pangan dan pakan ternak yang bergizi tinggi, kacang tanah mengandung lemak $(40,50 \%)$, protein (27\%), karbohidrat serta vitamin (A, B, C, $\mathrm{D}$, $\mathrm{E}$ dan $\mathrm{K}$ ), juga mengandung mineral antara lain Calcium, Chlorida, Ferro, Magnesium, Phospor, Kalium dan Sulphur (Dirjen Tanaman Pangan, 2012).

Menurut Sumarno (2015),
produktivitas kacang tanah sangat beragam, berkisar dari 0,5 t/ha hingga 3 t/ha polong kering. Produktivitas tertinggi diperoleh dari Amerika Serikat dan Australia, yang mencapai 3 t/ha polong kering. Produktivitas kacang tanah di negara-negara tropis, termasuk Indonesia, India, negara-negara di Afrika, pada umumnya hampir sama, antara 0,7 t/ha hingga 1,3 t/ha polong kering.

Data BPS (2017) juga menunjukan bahwa pada tahun 2016 produksi kacang tanah di Indonesia adalah mencapai 570.477 ton dengan luas panen sebesar 436.382 ha dangan produktivitas sebesar 1,3 t/ha. Sedangkan untuk provinsi Jambi, produksi kacang tanah berfluktasi yaitu 1.461 ton di tahun 2014, turun menjadi 1.176 pada tahun 2015 dan naik menjadi 1.213 ton di tahun 2016 dengan luas panen 1.139 ha ditahun 2014, turun menjadi 907 ha di tahun 2015 dan naik menjadi 947 ha di tahun 2016 dengan rata-rata produksi masih rendah yaitu 1,28 ton/ha. Rendahnya rata-rata produksi kacang tanah juga terjadi di Kabupaten Bungo, hal ini terlihat dari data BPS Bungo (2016) yaitu rata-rata hasil kacang pada tahun 2015 hanya mencapai 1,18 ton/ha.

Rendahnya produksi kacang tanah di kabupaten Bungo salah satunya diduga disebabkan oleh masalah kesuburan tanah relatif rendah, yang didominasi oleh tanah masam jenis ultisol dengan kandungan bahan organik yang rendah. Menurut Prasetyo (2006), kendala pada jenis tanah masam untuk pengembangan pertanian adalah kemasaman dan kejenuhan $\mathrm{Al}$ yang tinggi, dan tanah peka terhadap erosi, oleh karena itu kendala tersebut dapat diatasi dengan penerapan teknologi seperti pengapuran, pemupukan dan pengelolaan bahan organik.

Permasalahan dalam usahatani kacang tanah di lahan masam berhubungan dengan tingkat kesuburan tanah yang rendah dan tingkat kemasaman tanah yang tinggi sehingga perlu identifikasi kendalakendala dan cara pemecahannya. Menurut Setiono (2013), untuk meningkatkan pertumbuhan dan hasil kacang tanah per satuan hektar pada tanah masam jenis Ultisol, antara lain dapat dilakukan dengan memperbaiki sistim budidaya tanaman dengan cara meningkatkan kesuburan tanah. Purwasasmita dan Kurnia, (2009) menyatakan bahwa salah satu upaya yang dapat dilakukan untuk meningkatkan produksi kacang tanah adalah melalui inovasi teknik budidaya tanamannya, antara lain dengan pemberian larutan mikroorganisme lokal (MOL) yang disemprotkan pada tanaman/tanah, sebagai bioaktivator perombakan bahan organik yang berguna menambah ketersediaan hara makro dan mikro secara optimal bagi tanaman.

Larutan MOL adalah larutan fermentasi yang berbahan dasar dari berbagai sumberdaya yang tersedia. Larutan MOL mengandung bakteri yang berpotensi sebagai perombak bahan organik, perangsang pertumbuhan dan sebagai agen pengandalian hama penyakit pada tanaman, sehingga MOL dapat digunakan baik sebagai dekomposer, pupuk hayati dan pertisida organik terutama sebagai fungisida (Amalia, 2008). Pemanfaatan mikroorganisme lokal (MOL) yang mempunyai keuntungan dari segi biaya yang relatif murah dan kemudahan aplikasinya merupakan pilihan yang telah diterapkan oleh beberapa petani di beberapa daerah. Selain sebagai 
dekomposer, MOL juga digunakan sebagai pupuk dan pestisida hayati yang dapat diaplikasikan langsung ke tanaman (Sisworo, 2006). Pupuk hayati menambahkan nutrisi melalui proses alami, yaitu fiksasi nitrogen atmosfer, menjadikan fosfor bahan yang terlarut, dan merangsang pertumbuhan tanaman melalui sintesis zat-zat yang mendukung pertumbuhan tanaman (Sutanto, 2002).

Rebung adalah salah satu jenis tanaman yang potensial untuk di ekstrak menjadi MOL karena tingginya kandungan zat pengatur tumbuh. Menurut Pudjianto (2014), rebung atau tunas bambu yang masih muda dapat digunakan sebagai bahan untuk membuat MOL (mikroorganisme lokal) karena banyak mengandung mikroorganisme yang bermanfaat bagi pertumbuhan tanaman. MOL dari rebung bambu berfungsi sebagai zat perangsang pertumbuhan pada fase vegetatif. Mikroorganisme lokal mengandung zat yang dapat merangsang pertumbuhan tanaman dan zat yang mampu mendorong perkembangan tanaman seperti giberilin, sitokinin, auksin dan inhibitor (Mauludin, 2009). Amalia, (2008) menyatakan bahwa MOL rebung bambu mengandung $C$ Organik, Giberellin, Azotobacter dan Azospirillium yang tinggi untuk merangsang pertumbuhan tanaman secara cepat.

Hasil penelitian Fauzi, dkk (2013) menunjukkan bahwa pemberian konsentrasi MOL rebung bambu memberikan pertumbuhan dan pengaruh nyata terhadap pertumbuhan tanaman kailan pada tanah gambut. Pemberian MOL rebung bambu dengan yang paling efektif untuk pertumbuhan tanaman kailan adalah konsentrasi $10 \mathrm{ml} / \mathrm{l}$ air.

Adapun tujuan dari penelitian ini adalah untuk mengetahui karakteristik agronomi kacang tanah (Arachis hypogaea L.) di lahan masam pada pemberian mikroorganisme lokal (MOL) rebung bambu dan mendapatkan kosentrasi MOL yang terbaik terhadap karakteristik agronomi kacang tanah (Arachis hypogaea L.) di lahan masam Kabupaten Bungo.

\section{METODE PENELITIAN}

Penelitian dilaksanakan di kebun percobaan Fakultas Pertanian Universitas Muara Bungo Sungai Binjai KM 6 Kabupaten Bungo, dengan ketinggian \pm $101 \mathrm{~m}$ dpl, dengan curah hujan 248,75 $\mathrm{mm} /$ bulan (Monografi Kelurahan Sungai Binjai, 2015). Penelitian dilakukan pada tanggal 4 Juni 2018 sampai 30 September 2018. Penelitian ini menggunakan Rancangan Acak Kelompok (RAK) dengan 5 perlakuan dan 4 kelompok yaitu : M0 $=0 \mathrm{ml} /$ liter air, M1 = $10 \mathrm{ml} /$ liter air, M2 = $20 \mathrm{ml} /$ liter air, M3 = $30 \mathrm{ml} /$ liter air dan M4 = $40 \mathrm{ml} / \mathrm{liter}$ air

Tiap petak percobaan ada 20 tanaman maka jumlah tanaman seluruhnya sebanyak 400 tanaman, tiap petak diambil 4 tanaman sampel, maka jumlah tanaman sampel ada 80 sampel. Denah percobaan dan tata letak tanaman dapat dilihat pada lampiran 1 dan 2.

Pelaksanaan penelitian di mulai dengan pembuatan MOL yang dilakukan dua minggu sebelum tanam dengan cara sebagai berikut :

1. Bahan yang digunakan :

- Ember/drum plastik

- Slang

- botol aqua

- tali dan plastik.

- Rebung bambu kurang lebih 1 kg,

- Air kelapa 2,5 liter,

- Gula merah 1,5 ons.

2. Cara pembuatan

Rebung bambu di tumbuk halus atau diiris-iris dan dimasukkan pada ember/tong plastik. Campurkan dengan gula merah yang sudah dihaluskan dan aduk sampai rata, Rendam dengan air kelapa sebanyak 2,5 liter, Tutup rapat ember/drum plastik dengan plastik, dan berikan slang plastik yang disambungkan 
dengan air yang berada pada botol aqua. Biarkan selama 15 hari. Setelah 15 hari MOL siap digunakan, untuk pengenceran disesuaikan dengan perlakuan (Litbang Jambi, 2017)

Persiapan lahan diawali dengan pengukuran lahan sesuai dengan yang di kehendaki, kemudian membersihkan lahan dari segala jenis gulma dilanjutkan pengolahan tanah pertama yaitu dengan cara di cangkul, pencangkulan pertama sedalam $30 \mathrm{~cm}$ yang berfungsi sebagai pemecahan bongkahan tanah agar tanah menjadi gembur. Kemudian lahan yang sudah diolah dibuat petak-petak percobaan yang berukuran $0,8 \times 1 \mathrm{~m}$. Setelah tanah di olah di beri dolomit 5 ton/ha (400 g/petak). Kapur di tebar merata di petak percobaan, setelah di kapur di beri pupuk kandang ayam 10 ton/ha (800 g/petak). Untuk memudahkan dalam pengamatan maka setiap petakan diberi label sesuai dengan denah. Benih kacang tanah yang digunakan adalah varietas kelinci yang diperoleh dari Balai Benih Dinas Tanaman Pangan dan Hortikultura Kabupaten Bungo. Seleksi benih dilakukan perendaman selama 30 menit. Penanaman dilakukan dengan menggunakan tugal dengan kedalaman lubang tanam $3 \mathrm{~cm}$ dan tiap lubang diisi 2 butir benih kacang tanah, dengan menggunakan jarak tanam $20 \times 20 \mathrm{~cm}$ sehingga jumlah tanaman setiap unit petak percobaan sebanyak 20 tanaman. Pemberian MOL dilakukan setelah tanaman berumur 14 hari setelah tanam dengan cara disemprotkan kedaun dan batang dengan sprayer genggam. Penyemprotan dilakukan pada pagi hari antara pukul 08.00 - 10.00 WIB dengan konsentrasi sesuai perlakuan dengan interval penyemprotan 1 minggu sekali sampai umur 35 hst.

Adapun pemeliharaan yang
dilakukan adalah penyulaman yang
dilakukan 1 minggu setelah tanam.
Tanaman untuk sulaman diambil dari
tanaman cadangan yang sama
pertumbuhannya dengan tanaman
dilapangan. Penyiangan dilakukan

dilakukan pada umur 35 hst karena adanya pertumbuhan gulma di lahan penelitian. Penyiangan dilakukan dengan cara mencabut gulma dan mencangkul. pembumbunan dilakukan untuk memudahkan ginofor-ginofor menembus lapisan tanah yang kemudian membentuk polong. Pembumbunan dilakukan setelah proses pembungaan yaitu pada umur 27 hst dengan cara meninggikan tanah yang terletak pada bagian bawah. Setelah benih kacang tanah ditanam, dilakukan penyiraman satu kali sehari, selanjutnya interval yang dilakukan yaitu penyiraman dua kali sehari pada pagi dan sore hari, kecuali bila keadaan tanah telah lembab atau hujan.

Panen kacang tanah dilakukan pada umur 95 hst dimana $75 \%$ dari daun-daun tanaman telah menguning dan polong sudah tua. Tanda-tanda polong siap panen (tua) adalah berwarna coklat dan keras, bila dibuka biji telah berisi penuh dan kulit biji sudah kelihatan tipis berwarna merah muda

Parameter yang diamati dalam penelitian ini adalah Tinggi Tanaman (cm), Jumlah tangkai daun, jumlah Polong / tanaman (buah), Berat Polong kering / tanaman (g) dan Hasil Polong Kering /ha (ton). Untuk mengetahui pengaruh mikroorganisme lokal (MOL) dianalisis secara statistik dengan menggunakan analisis ragam, apabila berpengaruh nyata maka dilanjutkan dengan uji jarak Berganda Duncan Multipe Range Test (DMRT) pada taraf $5 \%$ (Steel and Torrie, 1994)

\section{HASIL DAN PEMBAHASAN}

\section{Tinggi Tanaman (cm)}

Berdasarkan hasil analisis ragam menunjukkan bahwa Mikroorganisme Lokal (MOL) rebung tidak berpengaruh nyata terhadap tinggi tanaman (Lampiran 6). Rataan tinggi tanaman pada masingmasing pengaruh Mikroorganisme Lokal (MOL) rebung dapat dilihat pada Tabel 1. 
Tabel 1. Rataan Tinggi Tanaman Kacang Tanah Pengaruh mikroorganisme lokal (MOL) Rebung

\begin{tabular}{lc}
\hline \multicolumn{1}{c}{ Perlakuan } & $\begin{array}{c}\text { Rataan } \\
(\mathrm{cm})\end{array}$ \\
\hline M0 $=0 \mathrm{ml} /$ liter air & 37,43 \\
$\mathrm{M} 1=10 \mathrm{ml} /$ liter air & 41,96 \\
$\mathrm{M} 2=20 \mathrm{ml} /$ liter air & 41,09 \\
$\mathrm{M} 3=30 \mathrm{ml} /$ liter air & 39,59 \\
$\mathrm{M} 4=40 \mathrm{ml} /$ liter air & 41,76 \\
\hline $\mathrm{KK}=9,53 \%$ & \\
\hline Keterangan : & Perlakuan tidak berpengaruh \\
\multicolumn{2}{c}{ nyata terhadap tinggi } \\
\multicolumn{2}{c}{ tanaman (cm) $(\mathrm{P}>0,05)}$.
\end{tabular}

Tabel 1 menunjukan bahwa pemberian MOL rebung bambu tidak berpengaruh nyata terhadap tinggi tanaman kacang tanah secara statistik ( $\mathrm{P}>0,05)$. Namun dilihat dari rataan yang dihasilkan, pemberian MOL rebung dapat direspon oleh tanaman sehingga karakteristik agronomi kacang tanah dalam hal ini tinggi tanaman lebih tinggi dibandingkan dengan tanpa perlakuan MOL rebung. Hal ini diduga kacang tanah yang dapat mengambil $\mathrm{N}$ dari hasil fiksasi belum mencukupi terhadap pertumbuhan sehingga penambahan MOL rebung bermanfaat bagi pertumbuhan tinggi tanaman kacang tanah.

Hal ini diperkuat oleh Taufiq dan Kristiono (2015) yang menyatakan bahwa anggapan tentang kacang tanah tidak perlu tambahan pupuk $\mathrm{N}$ karena dapat mengambil $\mathrm{N}$ dari hasil fiksasi tidak sepenuhnya benar karena kacang tanah banyak membutuhkan $\mathrm{N}$ pada awal pertumbuhannya ketika aktifitas bakteri Rizobium yang menfiksasi $\mathrm{N}$ belum bekerja/berfungsi secara aktif.

Menurut Mardhiastuti $d k k$ (2015), MOL rebung bambu mengandung zat pengatur tumbuh yang dapat memacu pertumbuhan tanaman. Sedangkan menurut Maspary (2010) MOL rebung mengandung $\mathrm{C}$ organik, Giberellin, Azotobacter dan Azospirillium yang tinggi untuk merangsang pertumbuhan tanaman secara cepat. Haryadi (2007) menjelaskan bahwa gibberellin adalah salah satu golongan ZPT dengan rangka entgibberellin yang berfungsi merangsang pembelahan sel, pemanjangan sel, dan fungsi pengatur tinggi tanaman.

Sedangkan menurut Suiatna (2010) Azospirillium $s p$ merupakan bakteri yang memfiksasi $\mathrm{N}$ di udara yang bersifat non simbiotik. Disamping peranannya secara langsung dalam peningkatan kandungan $\mathrm{N}$ tanaman, azospirililum sp. juga mampu menghasilkan fitohormon yang dapat merangsang pertumbuhan tanaman antara lain, auksin, gibberellin, dan sitokinin. Unsur $\mathrm{N}$ merupakan unsur terpenting dalam proses pertumbuhan vegetatif tanaman, seperti yang diutarakan Novizan (2002) bahwa $\mathrm{N}$ merupakan unsur hara utama yang sangat dibutuhkan untuk pertumbuhan vegetatif seperti akar, batang, dan daun.

\section{Jumlah Tangkai Daun (batang)}

Berdasarkan hasil analisis ragam menunjukkan bahwa Mikroorganisme Lokal (MOL) rebung tidak berpengaruh nyata terhadap jumlah tangkai daun (Lampiran 8). Rataan jumlah tangkai daun pada masing-masing pengaruh Mikroorganisme Lokal (MOL) rebung dapat dilihat pada Tabel 2.

Tabel 2. Rataan Jumlah Tangkai Duan Kacang Tanah Pengaruh Mikroorganisme Lokal (MOL) Rebung

\begin{tabular}{cc}
\hline \multicolumn{1}{c}{ Perlakuan } & $\begin{array}{c}\text { Rataan } \\
\text { (batang) }\end{array}$ \\
\hline M0 $=0 \mathrm{ml} /$ liter air & 6,38 \\
M1 $=10 \mathrm{ml} /$ liter air & 7,25 \\
M2 $=20 \mathrm{ml} /$ liter air & 7,56 \\
M3 $=30 \mathrm{ml} /$ liter air & 7,00 \\
M4 $=40 \mathrm{ml} /$ liter air & 7,88 \\
\hline KK $=20,65 \%$ &
\end{tabular}

Keterangan : Perlakuan tidak berpengaruh nyata terhadap jumlah 


\section{tangkai daun (batang) $(\mathrm{P}>0,05)$.}

Tabel 2 juga menunjukan bahwa pemberian MOL rebung bambu tidak berpengaruh nyata terhadap jumlah tangkai daun kacang tanah secara statistik $(P>0,05)$. Secara matematis rataan jumlah tangkai daun kacang tanah yang dihasilkan dari pemberian MOL rebung terlihat lebih banyak. Hal ini karena unsur hara yang terkandung dalam MOL rebung bambu dapat dimanfaatkan dan diserap oleh tanaman kacang tanah sehingga karakteristik agronomi kacang tanah dalam hal ini jumlah tangkai lebih banyak dibandingkan dengan tanpa pemberian MOL rebung.

Menurut Batara (2015), MOL rebung mengandung $0,03 \% \mathrm{~N}, 0,05 \% \mathrm{P}$, 0,60\% K, 15 ppm Fe, 0,3 ppm Cu dan 3,8 ppm $\mathrm{Cu}$. Menurut Buckman dan Brady (1982) unsur hara $\mathrm{N}$, dan $\mathrm{Fe}$ sangat dibutuhkan untuk pembentukan klorofil dan sintesa protein yang dikandung dalam khloroplas dan merangsang pertumbuhan vegetatif tanaman seperti menambah jumlah tangkai daun. Jika tumbuhan kekurangan unsur hara baik makro maupun mikro dan proses fotosintesis terganggu maka akan mempengaruhi pertumbuhan dan perkembangan tanaman. Menurut Haryadi (2007), komposisi dan kadar unsur hara makro ataupun mikro sangat berpengaruh terhadap tanaman, karena itu pemberian pupuk harus seimbang sesuai dengan kebutuhan tanaman.

Dengan tingginya tanaman maka jumlah tangkai daun juga banyak karen menurut Rukamana (2000), ruas-ruas batang yang berada diatas permukaan tanah merupakan tempat tumbuh tangkai daun. Selanjutnya dikatakan bahwa setiap tangkai terdiri dari empat helai anak daun sehingga semakin banyak jumlah tangkai yang dihasilkan semakin banyak pula jumlah daun tanaman kacang tanah. Helaian daun bersifat nitritopic, yakni mampu menyerap cahaya matahari sebanyak-banyaknya.

Selain itu tinggi rendahnya pertumbuhan serta hasil tanaman kacang tanah dipengaruhi oleh dua faktor yaitu faktor internal dan faktor eksternal. Faktor internal merupakan faktor yang dipengaruhi oleh sifat genetik atau sifat turunan seperti umur tanaman, morfologi tanaman, daya hasil, kapasitas menyimpan cadangan makanan, ketahanan terhadap penyakit dan lain-lain. Faktor ekternal merupakan faktor lingkungan, seperti iklim, tanah dan biotik (Gardner et al., 1991).

\section{Jumlah Polong / tanaman (buah)}

Berdasarkan hasil analisis ragam menunjukkan bahwa Mikroorganisme Lokal (MOL) rebung tidak berpengaruh nyata terhadap jumlah polong pertanaman (Lampiran 8). Rataan jumlah polong pertanaman pada masing-masing pengaruh Mikroorganisme Lokal (MOL) rebung dapat dilihat pada Tabel 3 .

Tabel 3. Rataan Jumlah Polong Pertanaman Kacang Tanah Pengaruh Mikroorganisme Lokal (MOL) Rebung

\begin{tabular}{lc}
\hline \multicolumn{1}{c}{ Perlakuan } & $\begin{array}{c}\text { Rataan } \\
\text { (buah) }\end{array}$ \\
\hline M0 $=0 \mathrm{ml} /$ liter air & 17,38 \\
M1 $=10 \mathrm{ml} /$ liter air & 22,69 \\
M2 $=20 \mathrm{ml} /$ liter air & 24,50 \\
M3 $=30 \mathrm{ml} /$ liter air & 20,81 \\
M4 $=40 \mathrm{ml} /$ liter air & 21,81 \\
\hline KK $=19,37 \%$ & \\
\hline
\end{tabular}

Keterangan: Perlakuan tidak berpengaruh nyata terhadap jumlah polong/tanaman (buah) $(\mathrm{P}>0,05)$.

Tabel 3 juga menunjukan bahwa pemberian MOL rebung bambu secara statisitik tidak berpengaruh nyata terhadap jumlah polong pertanaman kacang tanah $(\mathrm{P}>0,05)$. Rataan jumlah polong yang dihasilkan pada perlakuan pemberiaan MOL rebung sehingga karakteristik agronomi kacang tanah dalam hal ini 
jumlah polong pertanaman lebih tinggi dibandingkan tanpa MOL rebung meskipun secara statistik dianggap sama. Hal ini diduga bahwa pemberian MOL rebung melalui daun dapat dimanfaatkan oleh tanaman terutama unsur hara $\mathrm{P}$ dan $\mathrm{K}$ sehingga rataan jumlah polong yang mendapat perlakuan MOL rebung lebih tinggi meskipun perlakuan tidak berpengaruh nyata.

Winarso (2005) menambahkan bahwa fosfor di dalam tanaman mempunyai fungsi sangat penting dalam proses fosintesis, respirasi, transfer dan penyimpanan energi serta pembelahan dan pembesaran sel. Menurut Fahrudin (2009) kekurangan unsur $\mathrm{P}$ menyebabkan pertumbuhan sel tanaman akan tertunda dan apabila fospor dalam tanah tidak tersedia bagi tanaman pada awal pertumbuhan akan terhambatnya pertumbuhan generatif tanaman.

Unsur hara $\mathrm{K}$ yang tinggi pada MOL rebung $(0,6 \%)$ dapat dimanfaatkan oleh kacang tanah. Tanaman yang cukup mendapat kalium akan mampu membentuk jumlah polong yang banyak yang disebabkan oleh penyerapan air dan hara yang lebih baik dan translokasi yang lebih lancar. Novizan (2002), menyatakan bahwa unsur kalium diperlukan tanaman dalam sintesa protein dan karbohidrat serta translokasi karbohidrat lebih lancar. Apabila K kurang maka proses fotosintesis akan turun, tetapi respirasi tanaman akan meningkat. Selain itu defesiensi K dapat menyebabkan stomata membuka hanya sebagian dan menjadi lebih lambat dalam penutupan (Winarso, 2005).

Sedangkan menurut Yudiwanti dan Ghani (2002) bahwa, perbedaan jumlah polong ini dipengaruhi oleh jumlah cabang produktif dan persentase bunga yang membentuk polong. Lebih lanjut dikatakan bahwa Yudiwanti dan Ghani (2002) bahwa pembentukan polong dipengaruhi juga oleh ketersediaan hara dalam tanah, terutama kandungan unsur
P, K dan Ca. Ronoprawiro (2011) menambahkan bahwa kacang tanah memerlukan pasokan kalium yang cukup, apabila tidak tercukupi maka biji tidak jadi dihasilkan (polong kosong ). Sedangkan Menurut Stenly dkk., (2006) kacang tanah termasuk tanaman yang memerlukan sinar matahari penuh. Intensitas cahaya yang rendah pada saat pembentukan ginofor akan mengurangi jumlah ginofor, sedangkan rendahnya intensitas cahaya pada masa pengisian polong akan menurunkan jumlah dan berat polong serta akan menambah jumlah polong hampa.

Rataan jumlah polong tanaman kacang tanah pada penelitian berkisar pada 17,38 sampai 24,50 buah jika dibandingkan dengan deskripsi tanaman (lampiran 5) maka jumlah polong tanaman kacang tanah varietas kelinci yaitu \pm 15 buah sehingga rataan jumlah polong pada penelitian lebih banyak dibandingkan deskripsi tanaman.

\section{Berat Polong kering / tanaman (g)}

Hasil analisis ragam menunjukkan bahwa Mikroorganisme Lokal (MOL) rebung berpengaruh nyata terhadap berat polong kering pertanaman (Lampiran 9). Rataan berat polong pertanaman pada masing-masing pengaruh Mikroorganisme Lokal (MOL) rebung dapat dilihat pada Tabel 4.

Tabel 4. Rataan Berat Polong Pertanaman Kacang Tanah Pengaruh Mikroorganisme Lokal (MOL) Rebung

\begin{tabular}{cc}
\hline \multicolumn{1}{c}{ Perlakuan } & $\begin{array}{c}\text { Rataan } \\
(\mathrm{g})\end{array}$ \\
\hline $\mathrm{M} 0=0 \mathrm{ml} /$ liter air & $8,38 \mathrm{~b}$ \\
$\mathrm{M} 1=10 \mathrm{ml} /$ liter air & $9,25 \mathrm{~b}$ \\
$\mathrm{M} 2=20 \mathrm{ml} / \mathrm{liter}$ air & $11,63 \mathrm{a}$ \\
$\mathrm{M} 3=30 \mathrm{ml} / \mathrm{liter}$ air & $9,44 \mathrm{~b}$ \\
$\mathrm{M} 4=40 \mathrm{ml} /$ liter air & $9,06 \mathrm{~b}$ \\
\hline $\mathrm{KK}=12,98 \%$ & \\
\hline
\end{tabular}

Keterangan : Angka-angka yang di ikuti oleh huruf kecil yang 
berbeda pada kolom yang sama menunjukkan berbeda nyata menurut uji DNMRT pada taraf $5 \%$.

Dari Tabel 4 dapat dijelaskan bahwa perlakuan pemberian MOL rebung berpengaruh nyata terhadap berat polong pertanaman. Hasil penelitian juga menunjukan bahwa pelakuan M0 tidak berbeda dengan perlakuan M1, M2 dan M3 tapi berbeda nyata dengan perlakuan M2. Hal ini diduga pada perlakuan M2 merupakan perlakuan dengan unsur hara yang tersedia mencukupi dan seimbang terutama unsur hara $\mathrm{P}$ dan $\mathrm{K}$ yang berguna untuk pembentukan biji sehingga mempengaruhi berat kering polong pertanaman.

Sutedjo (2010), menambahkan bahwa unsur Fosfat berperan dalam membantu pertumbuhan protein dan mineral yang sangat tinggi bagi tanaman, dapat mempercepat pertumbuhan akar, dapat mempercepat serta memperkuat pertumbuhan tanaman muda menjadi tanaman dewasa, dapat mempercepat pembungaan dan pemasakan buah, biji dan juga dapat meningkatkan produksi biji-bijian. Hakim (1986) menjelaskan bahwa unsur fosfor berfungsi untuk mengubah karbohidrat seperti dalam perubahan tepung menjadi gula. Hasil perubahan karbohidrat tersebut akan berperan dalam pembentukan baik ukuran buah maupun berat nya, jika ketersediaan unsur fospor dalam tanah tersedia bagi tanaman maka akan menambah ukuran dan berat hasil panen. Selain itu fospor mampu meningkatkan kemampuan akar untuk menyerap unsur hara seperti N, P, dan K. Dimana fungsi nitrogen dan kalium sebagai pembentuk klorofil yang berguna sekali dalam proses fotosintesis, dengan adanya proses fotosintesis tersebut maka tanaman dapat menghasilkan karbohidrat dan protein yang berguna untuk pembentukan buah / polong yang dapat mempengaruhi jumlah dan berat polong.

\section{Hasil Polong Kering /ha (ton)}

Hasil analisis ragam menunjukkan bahwa Mikroorganisme Lokal (MOL) rebung berpengaruh nyata terhadap berat polong kering perhektar (Lampiran 11). Rataan berat polong kering per hektar pada masing-masing pengaruh Mikroorganisme Lokal (MOL) rebung dapat dilihat pada Tabel 5.

Tabel 5. Rataan Hasil Polong Kering Kacang Tanah Pengaruh Mikroorganisme Lokal (MOL) Rebung

\begin{tabular}{cr}
\hline \multicolumn{1}{c}{ Perlakuan } & \multicolumn{1}{c}{$\begin{array}{c}\text { Rataan } \\
\text { (ton/ha) }\end{array}$} \\
\hline $\mathrm{M} 0=0 \mathrm{ml} /$ liter air & $2,09 \mathrm{~b}$ \\
$\mathrm{M} 1=10 \mathrm{ml} /$ liter air & $2,31 \mathrm{~b}$ \\
$\mathrm{M} 2=20 \mathrm{ml} /$ liter air & $2,91 \mathrm{a}$ \\
$\mathrm{M} 3=30 \mathrm{ml} /$ liter air & $2,36 \mathrm{~b}$ \\
$\mathrm{M} 4=40 \mathrm{ml} /$ liter air & $2,27 \mathrm{~b}$ \\
\hline $\mathrm{KK}=12,98 \%$ & \\
\hline Keterangan & : Angka-angka yang di ikuti \\
& oleh huruf kecil yang \\
berbeda pada kolom yang & sama menunjukkan berbeda \\
& nyata menurut uji DNMRT \\
& pada taraf 5\%.
\end{tabular}

Dari Tabel 5 dapat dijelaskan bahwa perlakuan M0 tidak berbeda dengan perlakuan M1, M2 dan M3 tapi berbeda nyata dengan perlakuan M2. Hal ini diduga pada perlakuan M2 merupakan perlakuan dengan dapat meningkatkan mikroba tanah sehingga proses mineralisasi dapat berjalan optimal dan kebutuhan unsur hara bagi tanaman kacang tanah dapat terpenuhi. Disamping itu MOL rebung bambu unsur hara yang tersedia mencukupi dan seimbang terutama unsur hara $\mathrm{P}$ dan $\mathrm{K}$ sehingga mempengaruhi berat kering polong pertanaman.

Adapun fungsi fosfor terhadap tanaman antara lain sebagai bahan dasar pembentukan protein untuk meningkatkan energy ATP dan ADP dimana energy ini diperlukan dalam proses metabolism untuk pembentukan asam amino, tepung lemak dan senyawa organic lainnya sehinga 
mempercepat pembentukan bunga, buah dan pemasakan biji serta meningkatkan produksi biji-bijian (Lingga dan Marsono. 2013). Sedangkan Kalium lebih banyak berperan dalam pembentukan biji (Rosmarkan dan Yuwono, 2002). Taufiq dan Kristiono (2015) menyatakan kacang tanah memerlukan hara Kalium (K) tinggi, namun kandungan $\mathrm{K}$ yang tinggi pada daerah polong menyebabkan tingginya persentase polong hampa akibat terganggunya penyerapan $\mathrm{Ca}$. Winarso (2005) menyatakan apabila K kurang maka proses fotosintesis akan turun, tetapi respirasi tanaman akan meningkat. Selain itu defesiensi $\mathrm{K}$ dapat menyebabkan stomata membuka hanya sebagian dan menjadi lebih lambat dalam penutupan.

\section{KESIMPULAN}

\section{Kesimpulan}

1. Karakteristik agronomi tinggi tanaman (cm), jumlah tangkai daun (batang) dan jumlah polong pertanaman (buah), kacang tanah tidak ditentukan oleh pemberian MOL rebung bambau karena tidak berpengaruh nyata sedangkan berat polong kering pertanaman (g) dan hasil polong kering perhektar (ton) kacang tanah di lahan masam dalam penelitian ini ditentukan oleh pemberian MOL rebung bambu karena berpengaruh nyata.

2. Perlakuan MOL rebung bambu perlakuan M2 (20 ml/liter air) merupakan konsentrasi yang terbaik meningkatkan karakteristik agronomi kacang tanah di lahan masam.

\section{DAFTAR PUSTAKA}

Amalia. 2008. Pembuatan MOL (Mikroorganisme Lokal) Oleh Petani. http://Organicfield.
Wordpress.com/. diakses pada 25 Desember 2017

Badan Pusat Statistik. 2017. Produksi dan Luas Panen Kacang Tanah Menurut Provinsi, 2013 - 2016. Diunduh 20 Desember 2017

Batara, L.N. 2015. Kualitas Mikroorganisme Lokal (MOL) Yang Digunakan Pada Penanaman Padi (Oryza sativa L.) Dengan Metode System Of Rice Intensifcation (SRI) Organik. Tesis. Pasacasarjana IPB.

BPS Bungo. 2016. Luas Panen, Produksi dan Produktivitas Kacang Tanah Menurut Kecamatan di Kabupaten Bungo, 2016. http://bungokab.bps.go.id

Buckman, H.O. dan N.C.Brady. 1982. Ilmu Tanah. Te.jemahan. Bharata KaryaAksara. Jakarta

Dirjen tanaman Pangan, 2012. Road Map Peningkatan Produksi Kacang Tanah dan Kacang Hijau Tahun $2010-2014$.

Fahrudin, F. 2009. Budidaya Caisim (Brassica juncea L.) Menggunakan Ekstrak Teh Dan Pupuk Kascing. Skripsi.Fakultas Pertanian. Universitas Sebelas Maret. Surakarta.

Fauzi. G. Chairani. S, dan Dwi Zulfita. 2013. Pengaruh Konsentrasi Mikroorganisme Lokal (MOL) Rebung Bambu Terhadap Pertumbuhan Dan Hasil Tanaman Kailan Pada Tanah Gambut, Jurnal Sains Mahasiswa Pertanian. 
Gardner, FP., R.B. Pearse dan R.L. Mitchell. 1991. Fisiologi Tanaman Budidaya. H. Susilo (Penerjemah) Penerbit Universitas Indonesia. Jakarta. 428 Hlm. Terjemah dari: Fisiollogi of Crop Plants

Hakim, N., M. Y. Nyakpa, A. M. Lubis. S. G. Nugroho, M. R. Saul, M. A. Diha. H. H. Baily. 1986. Dasar-Dasar Ilmu Tanah. Universitas Lampung

Haryadi, S.S.M.M. 2007. Pengantar Agronomi. Gramedia Pustaka Utama. Jakarta

Maspary. 2010. Fungsi unsur hara dalam proses pertumbuhan dan perkembangan tanaman.Diakses dari:

http://www.gerbangpertanian.com/ 2014/03/ fungsi-unsur-harabagipertumbuhan-. Diunduh Oktober 2018

Mauludin. 2009. Pengembangan bahan organik melalui mikro organisme lokal, kompos dan pestisida nabati. http://gofreedomindonesia.com..

Diunduh 20 Desember 2017

Novizan. 2002. Petunjuk Pemupukan yang Efektif. Agromedia Pustaka, Jakarta

Prasetyo, B.H dan D.A. Suriadikarta, 2006. Karakteristik, potensi, dan teknologi Pengelolaan tanah ultisol untuk Pengembangan pertanian lahan Kering di indonesia. Balai Penelitian Tanah, Bogor.

Pudjianto, 2014. Mikroorganisme Lokal (MOL) Rebung Bambu. http://agritani.blogspot.co.id/2014/04/mikroo rganismelokal-MOL-rebungbambu.html. Diunduh 24 Desember 2017
Purwanasasmita dan Kurnia, 2009. Mikroorganisme Lokal Sebagai Pemicu Siklus Kehidupan Dalam Bioreaktor Tanaman. Makalah Seminar Teknik Kimia ITB 19-20 Oktober 2009, Bandung.

Ronoprawiro, S. 2011. Pupuk dan Pemupukan. Rineka Cipta. Jakarta.

Rosmarkum, A., dan N.M Yuwono. 2002. Balai Kesuburan Tanah. Kanisius, Yokyakarta

Rukmana, R. 2000. Kacang Tanah. Kanisius, Yokjakarta

Setiono. 2013. Komponen Hasil Dan Hasil Kacang Tanah Terhadap Pemberian Pupuk Kandang Sapi Dan Dolomit Di Tanah Masam Jenis Ultisol. Jurnal Sains Agro e-issn 2580$0744 . \quad$ http://ojs.umbbungo.ac.id/index.php/saingro/inde x. Diunduh 02 Januari 2018.

Sisworo, W.H., 2006. Swasembada Pangan dan Pertanian Berkelanjutan. Tantangan Abad Dua Satu : Pendekatan Ilmu Tanah, tanaman dan Pemanfataan Iptek Nuklir. Dalam A. Hanafiah WS, Mugiono,dan E.L. Sisworo. Badan Tenaga Nuklir Nasional, Jakarta.

Steel, R, G, D dan J,H,Torrie. 1994. Prinsip dan Prosedur Statistika Suatu Pendekatan BO Metrik. Penerbit PT. Gramedia Pustaka Utama. Jakarta

Stenly, K., A. C. Turang, dan J. Wowiling. 2006. Teknik Budidaya Kacang Tanah. Balai Pengkajian Teknologi Pertanian.

Suiatna, R,U., 2010. Bertani Padi Organik Pola Tanam Sri. Penerbit Padi Bandung. Bandung. 
Sumarno. 2015. Status Kacang Tanah Di Indonesia. Pusat Penelitian dan Pengembangan Tanaman Pangan. Monograf Balitkabi No. 13. Diunduh 24 Desember 2017

Sutanto, R. 2002. Penerapan Pertanian Organik Pemasyarakatan dan Pengembangannya. Kanisius, Yogyakarta.

Sutedjo, M. M., 2010. Pupuk dan Cara Pemupukan. Rineka Cipta. Jakarta.

Taufiq. A dan A. Kristiono. 2015. Keharaan Tanaman Kacang Tanah. Monograf Balitkabi No. 13. Balai Penelitian Tanaman Aneka Kacang dan Umbi

Winarso, S. 2005. Kesuburan Tanah Dasar Kesehatan dan Kualitas Tanah. Gava Media. Yogyakarta.

Yudiwanti, dan M.A. Ghani. 2002. Keragaan Daya Hasil GalurGalurKacang Tanah Hasil Persilangan Varietas Gajah dengan Galur GPNC-WS4. Makalah Seminar NasionalAgronomi. Perhimpunan Agronomi Indonesia (PERAGI). Bogor. 